Analytical Methods

\title{
Validation of a HPLC method for simultaneous determination of main organic acids in fruits and juices
}

\author{
Rodrigo Scherer ${ }^{\mathrm{a}}$, Ana Cecília Poloni Rybka ${ }^{\mathrm{a}}$, Cristiano Augusto Ballus ${ }^{\mathrm{a}}$, Adriana Dillenburg Meinhart ${ }^{\mathrm{a}}$, \\ José Teixeira Filho ${ }^{b}$, Helena Teixeira Godoy ${ }^{a, *}$ \\ a Department of Food Science, Faculty of Food Engineering, University of Campinas (UNICAMP), 13083-862 Campinas, SP, Brazil \\ ${ }^{\mathrm{b}}$ Faculty of Agricutural Engineering, University of Campinas (UNICAMP), 13083-862 Campinas, SP, Brazil
}

\section{A R T I C L E I N F O}

\section{Article history:}

Received 21 December 2009

Received in revised form 8 September 2011

Accepted 25 March 2012

Available online 13 April 2012

\section{Keywords:}

Liquid chromatography

Organic acids

Method validation

Fruit juices

Ascorbic acid stability

\begin{abstract}
A B S T R A C T
A liquid chromatographic method for fast and simultaneous determination of tartaric, malic, ascorbic and citric acids was validated for further application to fruits and juices. Moreover, the organic acids content of commercial samples of fruits and juices were evaluated, as well as the ascorbic acid stability during the storage. Determination of organic acids was carried out using a liquid chromatograph coupled to a diode array detector, with reversed phase $\left(\mathrm{C}_{18}\right.$ column) and isocratic elution with $0.01 \mathrm{~mol} \mathrm{~L}^{-1} \mathrm{KH}_{2} \mathrm{PO}_{4}$ $(\mathrm{pH}=2.60)$ mobile phase. The validation parameters showed efficiency, adequate linearity, relative standard deviation values between $0.4 \%$ and $2.3 \%(n=10)$ for repeatability and from $1.2 \%$ to $5.0 \%(n=18)$ for reproducibility, limits of detection (LD) were between 0.03 and $3.31 \mu \mathrm{g} \mathrm{mL}^{-1}$ and quantification (LQ) were between 0.10 and $11.03 \mu \mathrm{g} \mathrm{mL}^{-1}$, recovery rates were between $82 \%$ and $110 \%$, for two levels. In addition, the method is fast (10 $\mathrm{min})$ and generates low and non-toxic residues. The values found for vitamin $C$ were about 10 times above the values declared at the package. Ready to drink juices have a composition similar to the fruit, concerning to organic acids, except for the powder juice, in which only ascorbic and citric acids were found, for all tastes. After opening the package, a decrease of $14.0 \%$ and $27.0 \%$ in ascorbic acid content was observed for orange powder and ready to drink juices, respectively.

(c) 2012 Elsevier Ltd. All rights reserved.
\end{abstract}

\section{Introduction}

Organic acids are natural compounds in fruits and vegetables. The nature and concentration of the organic acids in fruits are of interest because of their important influence on the organoleptic properties and stability of fruit juices. The organic acid profile and concentration in fruits and vegetables depends on factors such as species, soil and stress conditions to which the fruit was submitted (Jones, 1998). They are also used extensively as food additives in the manufacture of beverages, fruit and vegetable drinks and juices. The main acids used to enhance beverages are citric, malic and tartaric as acidulants and ascorbic as an antioxidant.

Citrus juices are highly appreciated and consumed because of their taste and high vitamin C content. The shelf life evaluation is based on the evolution of vitamin $C$ during storage, although there are other quality parameters such as colour and flavour. Vitamin C is a very important vitamin for human nutrition that is supplied by fruits and vegetables. L-ascorbic acid is the main biologically active form of vitamin C. As a potent antioxidant, it has the capacity to eliminate several different free radicals (Davey et al., 2000). However, and because of its nature, vitamin $\mathrm{C}$ is oxidized and lost during

\footnotetext{
* Corresponding author. Tel.: +55 193521 4024; fax: +55 1935212153 .

E-mail address: helena@fea.unicamp.br (H.T. Godoy).
}

the storage period of the juice. There are several reports about ascorbic acid stability in juices (Castro, Scherer, \& Godoy, 2006; Kabasakalis, Siopidou, \& Moshatou, 2000; Leizerson \& Shimoni, 2005; Min, Jin, Min, Yeom, \& Zhang, 2003; Ros-Chumillas, Belissario, Iguaz, \& López, 2007; Zerdin, Rooney, \& Vermue, 2003), but there are no reports about ascorbic acid stability after opening the package, and frequently the whole contents of the package are not consumed after opening. Thus, data on ascorbic degradation is very important to guarantee the nutritional value to the consumer.

An accurate and specific determination of the nutrient content of fruits is extremely important to understand the relationship between dietary intake and human health. Several methods have been reported to evaluate organic acids, such as spectrophotometry (Rebelein, 1961; Vereda, García de Torres, Rivero, \& Cano, 1998), enzymatic methods (Puchades, Herrero, Maquieira, \& Atienza, 1991), gas chromatography (Cocchi et al., 2006; Kóvacs, Mörtl, \& Kende, 2011; West \& Mauer, 2011) and capillary zone electrophoresis (Cortacero-Ramírez, Segura-Carretero, de Castro, \& FernándezGutiérrez, 2005; Mato, Huidobro, Simal-Lozano, \& Sancho, 2006). The AOAC official method (AOAC, 1990) for ascorbic acid is based on the titration with 2,6-dichlorophenolindophenol in an acidic solution. However, reversed-phase high performance liquid chromatography (RP-HPLC) has become more and more popular for analyzing certain mixtures of organic acids because of the simplicity, 
speed and stability of the method (Lian, Mao, Ye, \& Miao, 1999; Shui \& Leong, 2002; Wang, Gonzalez, Gbur, \& Aselage, 1993; Destandau et al., 2005; Fontannaz, Kilinc, \& Heudi, 2006; Hernández, Lobo, \& González, 2006; Kerem, Bravdo, Shoseyov, \& Tugendhaft, 2004; Kotani, Miyaguchi, Tomita, Takamura, \& Kusu, 2004).

The aim of this work was to validate a liquid chromatographic method for the fast and simultaneous determination of the main organic acids in fruits and juices (tartaric, malic, ascorbic and citric acids), as well as to analyze commercial samples of fruits and juices and evaluate the ascorbic acid stability after opening the package.

\section{Materials and methods}

\subsection{Reagents and samples}

The organic acid standards were purchased from Supelco (Bellefonte, USA) (organic acids kit, 47264) and potassium monobasic phosphate was from Merck (Darmstadt, Germany). All the water used in the study was ultrapure, obtained from a Direct- $Q^{\circledR}$ system (Millipore Corporation, France). The samples were obtained at different supermarkets from Campinas, SP, Brazil. The evaluated samples consisted at apple (red peel with firm texture), orange (yellow peel) and lemon ripened fruits, as well as ready to drink juices ( $1 \mathrm{~L}$ Tetra Pak ${ }^{\circledR}$ package) (apple, orange and grape) and powdered juices ( $30 \mathrm{~g}$ package) (apple, orange and cashew). The ready to drink juices and powdered juices presented recent fabrication date. All samples were obtained in three batches and each batch was formed by homogenizing the total content of three packages. For fruits, three ripened fruits formed a batch.

\subsection{Sample preparation}

For ready to drink juices, three packages of the same batch was homogenized $(3 \mathrm{~L}$ ) and an aliquot of $5 \mathrm{~mL}$ was added to $40 \mathrm{~mL}$ of mobile phase, filtered through a $0.45 \mu \mathrm{m}$ membrane (Millipore Corporation, France) and immediately injected into the chromatograph. For the powdered juice, three packages of the same batch were homogenized $(90 \mathrm{~g}$ ) and $3 \mathrm{~g}$ was added to $100 \mathrm{~mL}$ of water according to the manufacturer's instructions. After the powder has been completely dissolved, an aliquot of $5 \mathrm{~mL}$ was added to $40 \mathrm{~mL}$ of mobile phase, filtered through a $0.45 \mu \mathrm{m}$ membrane and immediately injected into the chromatograph. For ripened fruits, the juices obtained by hand squeezing the oranges and the lemons were filtered through filter paper and diluted with mobile phase (10 times) and injected into the chromatograph. For apples, $200 \mathrm{~g}$ was shaken with water $(400 \mathrm{~mL})$, filtered through qualitative filter paper (Whatman Grade 4, Whatman, USA), diluted with mobile phase (10 times), filtered through a $0.45 \mu \mathrm{m}$ membrane and injected into the chromatograph in the same way as it was described before. All the samples were prepared and analyzed in triplicate.

The effect of diluting the samples with mobile phase on the further ascorbic acid stability during analysis was evaluated. A same sample of ready to drink orange juice was analyzed every $15 \mathrm{~min}$ until 90 min, to verify if the ascorbic acid was stable during this period.

\subsection{Liquid chromatographic analysis and method validation}

Determination of tartaric, malic, ascorbic and citric acids was carried out according to Scherer, Rybka, and Godoy (2008). It was used a HP 1100 series (Agilent, Germany) liquid chromatograph equipped with degasser, quaternary pump, autosampler adjusted to $20 \mu \mathrm{L}$ volume injection, $\mathrm{RP}^{-\mathrm{C}_{18}}$ column ( $3 \mu \mathrm{m}$ particle size,
$150 \times 4.6 \mathrm{~mm} \mathrm{I.D.,} \mathrm{kept} \mathrm{at} 25^{\circ} \mathrm{C}$ ) and a UV-Visible diode array detector (DAD). The mobile phase consisted of $0.01 \mathrm{~mol} \mathrm{~L}^{-1} \mathrm{KH}_{2}$ $\mathrm{PO}_{4}$ buffer solution ( $\mathrm{pH}=2.60$ adjusted with o-phosphoric acid), using an isocratic elution procedure with a flow rate of

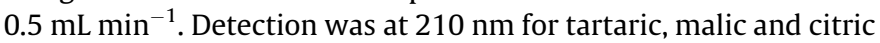
acids, and $250 \mathrm{~nm}$ for ascorbic acid.

The validation parameters consisted at linearity range, precision, accuracy and limits of detection and quantification (Ribani, Bottoli, Collins, Jardin, \& Melo, 2004). The peaks were identified by their retention times, comparing the UV-Visible spectra and spiking with standards. Quantification has been done using an external standard curve with seven points. The concentrations ranged from the quantification limits and 0.25, 0.5, 0.01 and $0.8 \mathrm{mg} \mathrm{mL}^{-1}$ for tartaric, malic, ascorbic and citric acids, respectively. The linearity range was evaluated by plotting the peak area corresponding to each analyte, as a function of the concentration introduced. Precision involved repeatability (10 successive injections, $n=10$ ) and intermediate precision (three injections on three different days in the same week, and this procedure was repeated after 6 months, totalizing $n=18$ ), both parameters being evaluated at two concentration levels. Accuracy was determined from the recovery rate at two concentration levels for each organic acid in each matrix. The limit of detection was the minimal concentration of the analyte giving a peak height that was three times the noise base line, and 10 times for the limit of quantification.

The differences were considered to be significant when $p<0.05$, and the data were analyzed using the software Statistica 6.0 (Statsoft, USA).

\subsection{Ascorbic acid stability}

Ascorbic acid stability was evaluated in powdered orange juice and ready to drink orange juice, after opening the package. For powdered juice, the whole content of one package from each of the three different batches was homogenized and diluted with water according to the manufacturer's instructions. Before injecting into the chromatograph, the juice was diluted again with mobile phase (10 times), filtered $(0.45 \mu \mathrm{m})$ and immediately injected. Ascorbic acid stability was evaluated in the orange powder juice every hour during $24 \mathrm{~h}$. For ready to drink juices, one package from each of the three different batches was analyzed. The juice was diluted with mobile phase (10 times), filtered $(0.45 \mu \mathrm{m})$ and immediately injected. The juices were kept at $5^{\circ} \mathrm{C}$ in a common freezer. The ascorbic acid stability was evaluated until 14 days after opening the package (every 2 days).

\section{Results and discussion}

The results of the validation parameters for the organic acids are shown in Table 1. A good linearity range was found and the precision parameters showed relative standard deviation (RSD) values between $0.4 \%$ and $2.3 \%$ for repeatability $(n=10)$ and from $1.2 \%$ to $5.0 \%$ for reproducibility $(n=18)$. These values are in agreement with Horwitz, Kamps, and Boyer (1980). The recovery rates were between $95 \%$ and $100 \%$ considering all the analyses at two concentration levels, except in apple fruit samples that show the lowest recovery rates in the lower level of addiction (82\% and $110 \%$ ). The limits of detection and quantification indicated high sensibility of the system, mainly for ascorbic acid. Ascorbic acid was monitored at $250 \mathrm{~nm}$ (Fig. 1A) due to the higher absorption (Fig. 1B), and also because the interferents were eliminated.

The trials realized to verify the effect of diluting the samples with mobile phase on the further ascorbic acid stability during analysis showed that there was no significant difference $(p>0.05)$ in the ascorbic acid concentration during the period 
Table 1

Validation parameters for the liquid chromatographic method.

\begin{tabular}{|c|c|c|c|c|c|c|c|}
\hline \multirow[t]{2}{*}{ Acid } & \multirow[t]{2}{*}{ Linearity $\left(r^{2}\right)$} & \multicolumn{2}{|c|}{ Repeatability $(n=10)^{a}$} & \multicolumn{2}{|c|}{ Reproducibility $(n=18)^{\mathrm{a}}$} & \multirow[t]{2}{*}{$\mathrm{LD}\left(\mu \mathrm{g} \mathrm{mL}^{-1}\right)^{\mathrm{b}}$} & \multirow[t]{2}{*}{$\mathrm{LQ}\left(\mu \mathrm{g} \mathrm{mL} \mathrm{L}^{-1}\right)^{\mathrm{c}}$} \\
\hline & & Level 1 (\%) & Level 2 (\%) & Level 1 (\%) & Level 2 (\%) & & \\
\hline Tartaric & 1.0000 & 0.38 & 1.28 & 1.59 & 0.85 & 0.72 & 2.40 \\
\hline Malic & 1.0000 & 0.43 & 0.96 & 2.52 & 1.36 & 3.31 & 11.03 \\
\hline Ascorbic & 0.9998 & 2.04 & 1.67 & 5.00 & 2.50 & 0.03 & 0.10 \\
\hline Citric & 0.9995 & 0.57 & 1.66 & 2.28 & 1.96 & 1.87 & 6.23 \\
\hline
\end{tabular}

a The concentration levels were: 1 and $190 \mathrm{mg} \cdot 100^{-1} \mathrm{~mL}$ for tartaric acid, 24 and $135 \mathrm{mg} \cdot 100^{-1} \mathrm{~mL}$ for malic acid, $0.6 \mathrm{and} 33 \mathrm{mg} \cdot 100^{-1} \mathrm{~mL}$ for ascorbic acid and 145 and $560 \mathrm{mg} \cdot 100^{-1} \mathrm{~mL}$ for citric acid.

b LD: limit of detection.

c LQ: limit of quantification.

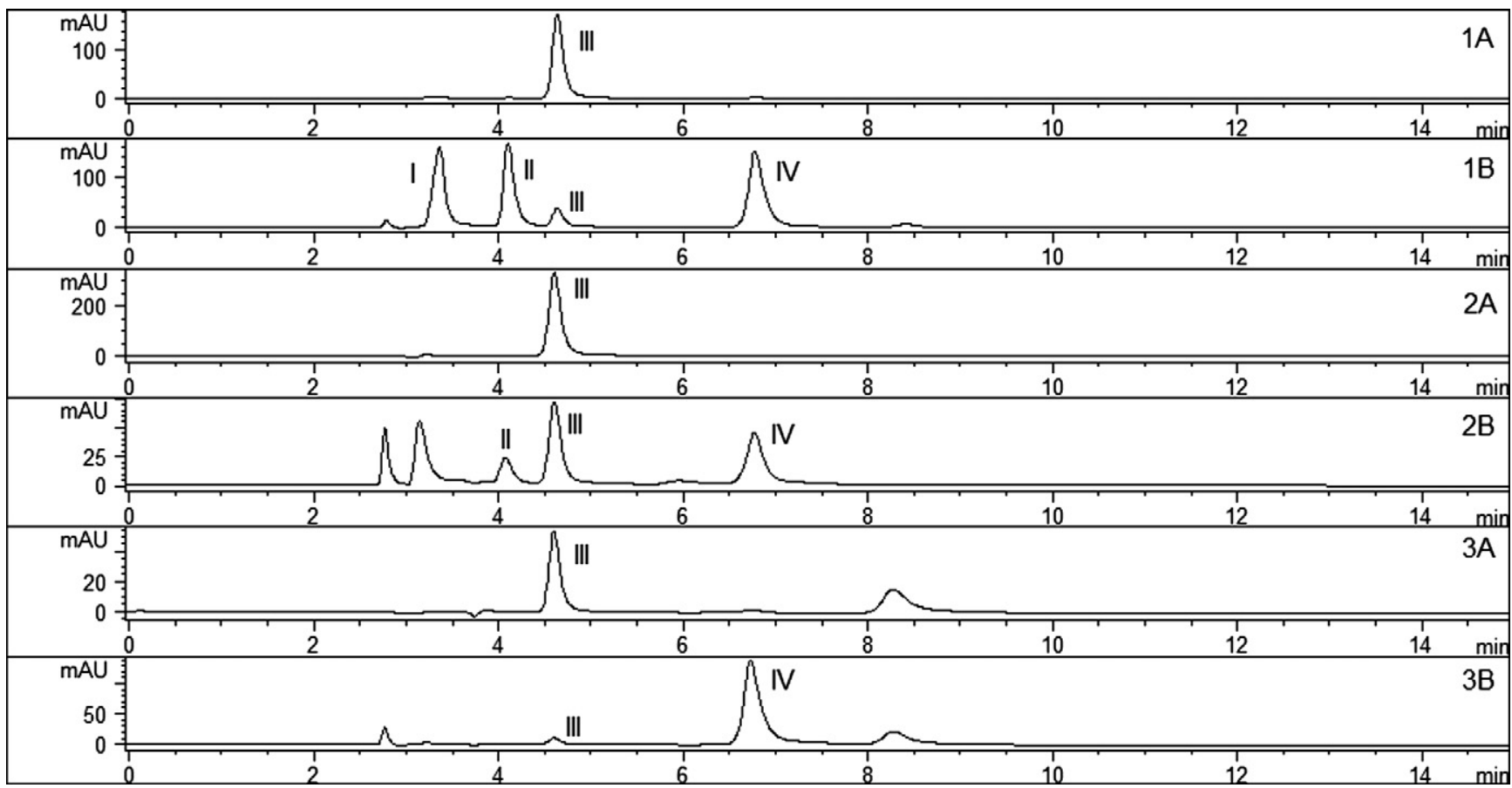

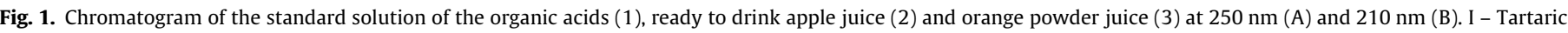
acid, II - malic acid, III - ascorbic acid and IV - citric acid.

studied. So, after sample dilution, they can be accurately analyzed in $90 \mathrm{~min}$, without loss of ascorbic acid.

Fig. 1 shows the chromatograms obtained for standard solution, ready to drink apple juice and orange powder juice at $210 \mathrm{~nm}$ and $250 \mathrm{~nm}$. It can be seen that the method presented good selectivity and resolution.

Table 2 shows the organic acids content of apple, orange and lemon juices. Tartaric and ascorbic acids were not found in apple fruit, only malic acid and traces of citric acid. Malic acid was the main acid in apple, showing concentrations between 130$201 \mathrm{mg} \cdot 100^{-1} \mathrm{~g}$ and only $2.75-9.68 \mathrm{mg} \cdot 100^{-1} \mathrm{~g}$ for citric acid. In Apples (Cv. Glockenapfel) $400-1000 \mathrm{mg} \cdot 100^{-1} \mathrm{~g}$ of malic acid and $5-8 \mathrm{mg} \cdot 100^{-1} \mathrm{~g}$ of citric acid have been reported (Ackermann, Fischer, \& Amadb, 1992). Chinnici, Spinabelli, Riponi, and Amati (2005) reported $100-500 \mathrm{mg} \cdot 100^{-1} \mathrm{~g}$ of malic acid in five commercial apple juices. Malic, ascorbic and citric acids were detected in the ready to drink apple juice, and in the apple powder juice the only acids found were ascorbic and citric acids. The label of ready to drink and powder juices declared the addition of ascorbic acid as antioxidant and citric acid as acidulant, but only the values for ascorbic acid were declared and the values found were greater than the declared values, about three times for the ready to drink juice and $50 \%$ for the powder juice.
The orange fruit and ready to drink juice showed a similar composition in relation to tartaric, malic, ascorbic and citric acids, but only ascorbic and citric acids were found in the powder juice. The values declared for ascorbic acid in the ready to drink juice was $34 \mathrm{mg} \cdot 100^{-1} \mathrm{~mL}$, and the mean of the three batches was 33 . $94 \mathrm{mg} \cdot 100^{-1} \mathrm{~mL}$. The value declared for the powder juice was 1 . $11 \mathrm{mg} \mathrm{g}^{-1}$ and the mean of the three batches was $1.30 \mathrm{mg} \mathrm{g}^{-1}$ (17\% higher).

In the three different lemons evaluated, tartaric, malic, ascorbic and citric acids were detected. The highest values for ascorbic and citric acids were found in the Citrus limon, and the highest values for tartaric and malic acids in Citrus aurantifolia (Table 2). Due to the higher acidity the major organic acid found was citric, between 5192 and $7696 \mathrm{mg} \cdot 100^{-1} \mathrm{~mL}$, in agreement with Karadeniz (2004), who reported 4854 and $6032 \mathrm{mg} \cdot 100^{-1} \mathrm{~mL}$ in lemon juices.

Ascorbic and citric acids were found in the grape powder juice, with means for the three batches of $1.05 \pm 0.2 \mathrm{mg} \mathrm{g}^{-1}$ and $122.10 \pm 13.35 \mathrm{mg} \cdot 100^{-1} \mathrm{~mL}$, respectively. The ready to drink cashew juice presented $8.42 \pm 0.16,39.07 \pm 11.98,54.02 \pm 11.77$ and $228.57 \pm 19.48 \mathrm{mg} \cdot 100^{-1} \mathrm{~mL}$ of tartaric, malic, ascorbic and citric acids, respectively, considering the mean of the three batches. The values declared for ascorbic acid in the grape powder 
Table 2

Organic acid contents in fruit and juices ${ }^{a}$.

\begin{tabular}{|c|c|c|c|c|c|}
\hline & Batch & Tartaric & Malic & Ascorbic & Citric \\
\hline & & Mean \pm SD & Mean \pm SD & Mean \pm SD & Mean \pm SD \\
\hline \multicolumn{6}{|c|}{ Apple fruit (Malus domestica) and juices } \\
\hline Ready to drink & 1 & $\mathrm{Nd}^{\mathrm{c}}$ & $72 \pm 3.1$ & $32.7 \pm 0.4$ & $212 \pm 3.3$ \\
\hline \multirow[t]{2}{*}{$\mathrm{mg} \cdot 100^{-1} \mathrm{~mL}$} & 2 & $\mathrm{Nd}$ & $79.5 \pm 0.7$ & $25.7 \pm 0.8$ & $212 \pm 1.8$ \\
\hline & 3 & $\mathrm{Nd}$ & $79 \pm 1.0$ & $30.8 \pm 0.6$ & $185 \pm 2.8$ \\
\hline Label value ${ }^{\mathrm{b}}$ & & $-{ }^{c}$ & - & 9.5 & - \\
\hline Fruit & 1 & $\mathrm{Nd}$ & $171 \pm 3.6$ & $\mathrm{Nd}$ & $9.6 \pm 0.9$ \\
\hline \multirow[t]{2}{*}{$\mathrm{mg} \cdot 100^{-1} \mathrm{~g}$} & 2 & $\mathrm{Nd}$ & $201 \pm 4.5$ & $\mathrm{Nd}$ & $3.8 \pm 0.3$ \\
\hline & 3 & $\mathrm{Nd}$ & $132 \pm 3.6$ & $\mathrm{Nd}$ & $2.7 \pm 0.3$ \\
\hline Label value & & - & - & - & - \\
\hline Powder & 1 & $\mathrm{Nd}$ & $\mathrm{Nd}$ & $1.8 \pm 0.14$ & $115 \pm 1.2$ \\
\hline \multirow[t]{2}{*}{$\mathrm{mg} \mathrm{g}^{-1}$} & 2 & $\mathrm{Nd}$ & $\mathrm{Nd}$ & $1.99 \pm 0.04$ & $113 \pm 2.7$ \\
\hline & 3 & $\mathrm{Nd}$ & $\mathrm{Nd}$ & $1.35 \pm 0.02$ & $101 \pm 6.0$ \\
\hline Label value & & - & - & 1.11 & - \\
\hline \multicolumn{6}{|c|}{ Orange (Citrus sinensis) and orange juices } \\
\hline Ready to drink & 1 & $15.2 \pm 0.6$ & $29 \pm 1.8$ & $32 \pm 1.2$ & $517 \pm 7.7$ \\
\hline \multirow[t]{2}{*}{$\mathrm{mg} \cdot 100^{-1} \mathrm{~mL}$} & 2 & $14 \pm 1$ & $52 \pm 2.4$ & $38 \pm 1.6$ & $529 \pm 9.5$ \\
\hline & 3 & $11.5 \pm 0.8$ & $56 \pm 1.7$ & $30 \pm 2.6$ & $519 \pm 4.6$ \\
\hline Label value & & - & - & 34 & - \\
\hline Fruit & 1 & $43.7 \pm 0.9$ & $17.9 \pm 0.9$ & $35 \pm 1.8$ & $969 \pm 53.8$ \\
\hline \multirow[t]{2}{*}{$\mathrm{mg} \cdot 100^{-1} \mathrm{~g}$} & 2 & $72 \pm 5.3$ & $21.5 \pm 0.2$ & $38.4 \pm 0.8$ & $692 \pm 17.4$ \\
\hline & 3 & $51 \pm 1.8$ & $39 \pm 1.9$ & $56 \pm 1.0$ & $1515 \pm 29.1$ \\
\hline Powder & 1 & $\mathrm{Nd}$ & $\mathrm{Nd}$ & $1.24 \pm 0.02$ & $182 \pm 14.7$ \\
\hline \multirow[t]{2}{*}{$\mathrm{mg} \mathrm{g}^{-1}$} & 2 & $\mathrm{Nd}$ & $\mathrm{Nd}$ & $1.6 \pm 0.2$ & $171 \pm 1.2$ \\
\hline & 3 & $\mathrm{Nd}$ & $\mathrm{Nd}$ & $1.02 \pm 0.01$ & $193 \pm 3.8$ \\
\hline Label value & & - & - & 1.11 & - \\
\hline \multicolumn{6}{|c|}{ Lemon $\left(\mathrm{mg} \cdot 100^{-1} \mathrm{~mL}\right)$} \\
\hline \multirow[t]{3}{*}{ Citrus aurantifolia } & 1 & $5.0 \pm 0.2$ & $709 \pm 30$ & $29 \pm 2.8$ & $6797 \pm 177$ \\
\hline & 2 & $3.9 \pm 0.2$ & $520 \pm 23$ & $29 \pm 1.0$ & $6581 \pm 61$ \\
\hline & 3 & $5.6 \pm 0.1$ & $534 \pm 20$ & $32.4 \pm 0.8$ & $7023 \pm 64$ \\
\hline \multirow[t]{3}{*}{ Citrus limonia } & 1 & $9.4 \pm 0.8$ & $1105 \pm 14$ & $14.2 \pm 0.9$ & $5500 \pm 119$ \\
\hline & 2 & $8.9 \pm 0.6$ & $1105 \pm 61$ & $13.6 \pm 0.8$ & $5765 \pm 16$ \\
\hline & 3 & $7.2 \pm 0.8$ & $965 \pm 12$ & $12 \pm 1.0$ & $5192 \pm 115$ \\
\hline \multirow[t]{3}{*}{ Citrus limon } & 1 & $6.1 \pm 0.1$ & $174 \pm 2$ & $42.2 \pm 0.6$ & $6407 \pm 201$ \\
\hline & 2 & $6.3 \pm 0.3$ & $463 \pm 1$ & $44.4 \pm 0.6$ & $7696 \pm 18$ \\
\hline & 3 & $6.10 \pm 0.04$ & $355 \pm 2$ & $42.9 \pm 0.4$ & $7586 \pm 16$ \\
\hline
\end{tabular}

\footnotetext{
d(-): Not declared.

a Results are expressed as mean $\pm \mathrm{SD}$ (standard deviation) $(n=3)$.

b Value from the label.

c Nd: Not detected.
}

juice and ready to drink cashew juice were $1.11 \mathrm{mg} \mathrm{g}^{-1}$ and $5.0 \mathrm{mg} \cdot 100^{-1} \mathrm{~mL}$, respectively. Thus the powder juice was in accordance, but the cashew juice presented 10 times more ascorbic acid than the value reported in the label.

The Brazilian legislation (ANVISA, 2003) allows a variation of up to $20 \%$ than the values declared in the label, with respect to the nutrient and caloric values. Thus, only the ready to drink orange juice and orange and grape powder juices were in accordance with Brazilian legislation.

The recommended dietary intake (RDI) is the intake sufficient to meet the nutrient requirement for nearly all healthy individuals in a group. The RDI is expressed as a single value given separately for each sex and specific age group. The magnitude of the discrepancy from the RDI and the duration of the nutritional deficit determine whether adverse effects on health and well being will occur. According to the Brazilian legislation (ANVISA, 1998) and Food and Agriculture Organization (FAO/WHO, 2002), the ascorbic acid RDI for adults is 60 and $45 \mathrm{mg}$, respectively. Thus, approximately $200 \mathrm{~mL}$ (one glass) of all ready to drink juices and fruits evaluated would supply the RDI, except for the apple fruit and Citrus limonia. However, for powder juices, more than $1000 \mathrm{~mL}$ are necessary, since instructions on the package recommend dissolving $30 \mathrm{~g}$ in $1000 \mathrm{~mL}$ of water.

The ascorbic acid stability was evaluated in the ready to drink orange juice during 14 days after opening the package (every
2 days). The labelling information recommended consumption in up to 3 days after opening the package. The results showed that after 4,8 and 10 days of storage, decreases of $9 \%, 20 \%$ and $27 \%$ $(p<0.05)$ was observed in the ascorbic acid content, as compared to when the package was opened (Fig. 2). No significant difference was observed after $8 \mathrm{~h}$, however, after $24 \mathrm{~h}$ a reduction of $14 \%$ in the ascorbic acid content was observed. Thus, there was low damage to the nutritional value of the powder juice in $24 \mathrm{~h}$.

\section{Conclusion}

The liquid chromatographic method described in this study allowed the investigation of tartaric, malic, ascorbic and citric acids in fruits and juices. All the validation parameters were in accordance to the Brazilian legislation requirements, since RSD values for precision were between $0.4 \%$ and $5.0 \%$, limits of detection and quantification obtained were adequate for sample analysis and recovery rates resulted between $95 \%$ and 100\%, except for apple fruit samples ( $82 \%$ and 100\%). The method is fast and leads to the organic acids separation in a 10 min run. Sample preparation is simple, needing only dilution and filtration before injection. Mobile phase consisted of a simple buffer, which is easily commercially found and has low cost. The final residue does not present toxicity and can be discarded after neutralization, since it does 


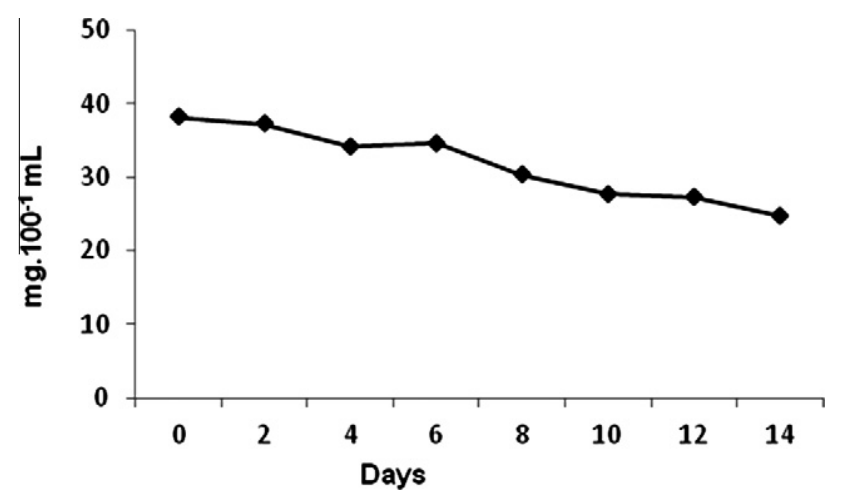

Fig. 2. Ascorbic acid stability in the ready to drink orange juice stored at $5{ }^{\circ} \mathrm{C}$ in a common freezer.

not cause any damages to the environment. So, the costs with reagents and residual treatment are very low, making this method a fast, efficient and environmental friendly choice to routine analysis. Of the six industrialized juices evaluated, three were not in accordance with the Brazilian legislation with respect to the values declared on the label. About $200 \mathrm{~mL}$ of all the juices supplied the RDI for vitamin C, except the powder juice, for whose it is necessary more than $1000 \mathrm{~mL}$. For the orange juices, the vitamin $\mathrm{C}$ contents decreased little during the period evaluated.

\section{Acknowledgements}

We would like to thank, for the financial support to this study, to FAPESP - Fundação de Amparo à Pesquisa do Estado de São Paulo, to Capes - Coordenação de Aperfeiçoamento de Pessoal de Nível Superior and to CNPQ - Coordenação Nacional de Desenvolvimento Científico e Tecnológico.

\section{References}

Ackermann, J., Fischer, M., \& Amadb, A. (1992). Changes in sugars, acids, and amino acids during ripening and storage of apples (CV. Glockenapfel). Journal of Agricultural and Food Chemistry, 40, 1131-1134.

ANVISA - Agência Nacional de Vigilância Sanitária (1998). Portaria n 222, de 24 de março de 1998. Brasília: Diário Oficial da União 2003 (23.05.98).

ANVISA - Agência Nacional de Vigilância Sanitária (2003). Resolução RDC n 360 de 23 de dezembro de 2003. Brasília: Diário Oficial da União 2003 (06.02.03).

AOAC - Official methods of analysis of the Association of Official Analytical Chemists (15th ed.) (1990). Arlington: Association of Official Analytical Chemists.

Castro, F. J., Scherer, R., \& Godoy, H. T. (2006). Avaliação do teor e da estabilidade de vitaminas do complexo $\mathrm{B}$ e vitamina $\mathrm{C}$ em bebidas isotônicas e energéticas. Química Nova, 29(4), 719-723.

Chinnici, F., Spinabelli, U., Riponi, C., \& Amati, A. (2005). Optimization of the determination of organic acids and sugars in fruit juices by ion-exclusion liquid chromatography. Journal Food Composition Analysis, 18, 121-130.

Cocchi, M., Durante, C., Grandi, M., Lambertini, P., Manzini, D., \& Marchetti, A. (2006). Simultaneous determination of sugars and organic acids in aged vinegars and chemometric data analysis. Talanta, 69(5), 1166-1175.

Cortacero-Ramírez, S., Segura-Carretero, A., de Castro, M. H. B., \& FernándezGutiérrez, A. (2005). Determination of low-molecular-mass organic acids in any type of beer samples by coelectroosmotic capillary electrophoresis. Journal of Chromatography A, 1064, 115-119.

Davey, M. W., Montagu, M. V., Sanmartin, D. I. M., Kanellis, A., Smirnoff, N., Benzie, I. J. J., et al. (2000). Plant L-ascorbic acid: Chemistry, function, metabolism, bioavailability and effects of processing. Journal of the Science of Food Agriculture, $80,825-860$.
Destandau, E., Vial, J., Jardy, A., Hennion, M. C., Bonnet, D., \& Lancelin, P. (2005). Development and validation of a reversed-phase liquid chromatography method for the quantitative determination of carboxylic acids in industrial reaction mixtures. Journal of Chromatography A, 1088, 49-56.

FAO/WHO - Food and Agriculture Organization of the United Nations and World Health Organization (2002). Human Vitamin and Mineral Requirements. Rome.

Fontannaz, P., Kilinc, T., \& Heudi, O. (2006). HPLC-UV determination of total vitamin $C$ in a wide range of fortified food products. Food Chemistry, 94, 626-631.

Hernández, Y., Lobo, M. G., \& González, M. (2006). Determination of vitamin C in tropical fruits: A comparative evaluation of methods. Food Chemistry, 96 654-664.

Horwitz, W., Kamps, L. R., \& Boyer, K. W. (1980). Quality assurance in the analysis of foods for traces constituents. Quality Control, 63(4), 1344-1347.

Jones, D. L. (1998). Organic acids in the rhizosphere a critical review. Plant Soil, 205, 25-44.

Kabasakalis, V., Siopidou, D., \& Moshatou, E. (2000). Ascorbic acid content of commercial fruit juices and its rate of loss upon storage. Food Chemistry, 70 325-328.

Karadeniz, F. (2004). Main organic acid distribution of authentic citrus juices in Turkey. Turkish Journal of Agriculture and Forestry, 28(4), 267-271.

Kerem, Z., Bravdo, B., Shoseyov, O., \& Tugendhaft, Y. (2004). Rapid liquid chromatography-ultraviolet determination of organic acids and phenolic compounds in red wine and must. Journal of Chromatography A, 1052, 211-215.

Kotani, A., Miyaguchi, Y., Tomita, E., Takamura, K., \& Kusu, F. (2004). Determination of organic acids by high-performance liquid chromatography with electrochemical detection during wine brewing. Journal of Agricultural and Food Chemistry, 52(6), 1440-1444.

Kóvacs, Á., Mörtl, M., \& Kende, A. (2011). Development and optimization of a method for the analysis of phenols and chlorophenols from aqueous samples by gas chromatography-mass spectrometry after solid-phase extraction and trimethylsilylation. Microchemical Journal, 99, 125-131.

Leizerson, S., \& Shimoni, E. (2005). Stability and sensory shelf life of orange juice pasteurized by continuous ohmic heating. Journal of Agricultural and Food Chemistry, 53(10), 4012-4018.

Lian, H. Z., Mao, L., Ye, X. L., \& Miao, J. (1999). Simultaneous determination of oxalic fumaric, maleic and succinic acids in tartaric and malic acids for pharmaceutical use by ion-suppression reversed-phase high performance liquid chromatography. Journal of Pharmaceutical and Biomedical Analysis, 19, 621-625.

Mato, I. Huidobro, J. F., Simal-Lozano, J., \& Sancho, M. T. (2006). Simultaneous determination of organic acids in beverages by capillary zone electrophoresis. Analytica Chimica Acta, 565(2), 190-197.

Min, S., Jin, Z. T., Min, S. K., Yeom, H., \& Zhang, Q. H. (2003). Commercial-scale pulsed electric field processing of orange juice. Journal of Food Science, 68(4), 1265-1271.

Puchades, R., Herrero, M. A., Maquieira, A., \& Atienza, J. (1991). Simultaneous enzymic determination of L-malic acid and L-lactic acid in wine by flow injection analysis. Food Chemistry, 42, 67-182.

Rebelein, H. (1961). Colorimetric determination of tartaric and lactic acids in wine and fruit juice. Deutsche Lebensmittel-Rundschau, 57, 6-41.

Ribani, M., Bottoli, C. B. G., Collins, C. H., Jardin, I. C. S. F., \& Melo, L. F. C. (2004) Validation for chromatographic and electrophoretic methods. Química Nova, 27, $771-780$.

Ros-Chumillas, M., Belissario, Y., Iguaz, A., \& López, A. (2007). Quality and shelf life of orange juice aseptically packaged in PET bottles. Journal of Food Engineering $79,234-242$.

Scherer, R., Rybka, A. C. P., \& Godoy, H. T. (2008). Determinação simultânea dos ácidos orgânicos tartárico, málico, ascórbico e cítrico em polpas de acerola, açaí e caju, e avaliação da estabilidade em sucos de caju. Química Nova, 31, 1137-1140.

Shui, G. \& Leong L. P. (2002). Separation and determination of organic acids and phenolic compounds in fruit juices and drinks by high-performance liquid chromatography. Journal of Chromatography A, 977, 89-96.

Vereda, E., García de Torres, A., Rivero, A., \& Cano, J. M. (1998). Determination of organic acids in wines. A review. Ouímica Analítica, 17, 167-175.

Wang, T., Gonzalez, A. R., Gbur, E. E., \& Aselage, J. M. (1993). Organic acid changes during ripening of processing peaches. Journal of Food Science, 58(3), 631-632.

West, E. M., \& Mauer, J. L. (2011). Development of an integrated approach for the stability testing of flavonoids and ascorbic acid in powders. Food Chemistry, 129, 51-58.

Zerdin, K., Rooney, M. L., \& Vermue, J. (2003). The vitamin C content of orange juice packed in an oxygen scavenger material. Food Chemistry, 82, 387-395. 